\title{
Comics as a Transmedial Phenomenon: From a PRINTED TO A DIGITAL MEDIUM
}

\author{
Victoria Yefymenko, Taras Shevchenko National University of Kyiv, \\ Ukraine, victoria.yefymenko@gmail.com
}

Original scientific paper

DOI: 10.31902/fII.35.2021.8

\begin{abstract}
Comics have recently attracted the increased attention of theorists as a very dynamic and fast-growing genre. A characteristic feature of contemporary comics is their transmediality, i.e., exceeding the boundaries of the printed page and transforming to digital narratives. Transition to a digital medium gives a number of advantages, including the possibility of using different display modes, deeper immersion in the fictional world, greater degree of interactivity. This paper examines comics, which are adaptations of the classic fairy tale Little Red Riding Hood, identifies intertextual references and modifications of the comics versions. Intertextual references can be traced at the level of comics titles, names of the characters and their characteristics, semi-quotes, which paraphrase the original texts, besides, comics have a different temporal and spatial setting, they extend the scope of the storyworld. Particular attention has been paid to the page layout, such comics-specific features as panels, frames, speech balloons, speed lines, emanata, and onomatopoeic words.

Print and digital comics are analysed using narratological and multimodal approaches. The analysis includes such narratological issues as narratorial and nonnarratorial strategies of representation, the temporal and spatial structure of a narrative, internal and external focalisation, as well as focalisation-marking devices (the eyeline match, the over-the-shoulder shot, the high-angle shot). A comic is a multimodal narrative, combining several modes, mainly visual and verbal. The aural mode is represented in comics by linguistic and visual signs, e.g., jagged borders of a speech balloon or the size and boldness of letters. Special attention has been given to the interaction between visual and verbal modes, in particular to the text-image relations. Our analysis has identified such types of the text-image relations as specification, exemplification, and enhancement.

Comics have recently attracted the increased attention of theorists as a very dynamic and fast-growing genre. A characteristic feature of contemporary comics is their transmediality, i.e. exceeding the boundaries of the printed page and transforming to digital narratives. Transition to a digital medium gives a number of advantages, including the possibility of using different display modes, deeper immersion in the fictional world, greater degree of interactivity. This paper examines comics, which are adaptations of the classic fairy tale Little Red Riding Hood, identifies intertextual references and modifications of the comics versions. Intertextual references can be traced at the level of comics titles, names of the characters and their characteristics, semi-quotes, which paraphrase the
\end{abstract}


original texts, besides, comics have a different temporal and spatial setting, they extend the scope of the storyworld. Particular attention has been paid to the page layout, such comics-specific features as panels, frames, speech balloons, speed lines, emanata, and onomatopoeic words.

Print and digital comics are analysed using narratological and multimodal approaches. The analysis includes such narratological issues as narratorial and nonnarratorial strategies of representation, the temporal and spatial structure of a narrative, internal and external focalisation, as well as focalisation-marking devices (the eyeline match, the over-the-shoulder shot, the high-angle shot). A comic is a multimodal narrative, combining several modes, mainly visual and verbal. The aural mode is represented in comics by linguistic and visual signs, e.g., jagged borders of a speech balloon or the size and boldness of letters. Special attention has been given to the interaction between visual and verbal modes, in particular to the text-image relations. Our analysis has identified such types of the text-image relations as specification, exemplification, and enhancement.

Keywords: comics, transmediality, multimodality, digital comics, webcomics, text-image relations, focalisation, Little Red Riding Hood, intertextuality.

\section{Introduction}

Comics is one of the youngest literary genres, which has been actively developing recently. It has been widely used in education as a tool for teaching various subjects (Berkowitz and Packer), multimodal literacy (Jacobs), developing analytical and critical thinking skills (Versaci). German comics critics Wegmann and Wolf write about comics as an "initially illegitimate genre [that] has over the last decades developed an unforeseen dynamic" (Kutch 2). Comics have emerged within the boundaries of the printed page in the form of newspaper comic strips and comic books, but recently have exceeded these boundaries and transformed to digital webcomics, hypercomics, and motion comics, thus becoming a transmedial phenomenon.

This paper has several goals: to summarize specific features of comics as a separate genre; to outline methodological approaches to the analysis of comics; to identify intertextual references to a traditional fairy tale and modifications of the comics versions; to define types of narrators and focalisers in comics; to reveal various types of relations between visual and verbal modes.

Comics have for a long time been in the intermediate state between a "genre" on the one hand and a "medium" on the other. For instance, Hescher points out that in comics studies the term 'comics' is considered as a plurimedial communication channel, as a genre combining different modes of writing, and as a multimodal discourse (40). While examining the interaction between genres and media, some 
authors consider genres as medium-specific discourses, because they evolve in different ways in various media (Labarre 17). We agree with those theorists who treat comics as a separate genre with its own set of narrative conventions and specific features. Comics genre may be used across media, e.g., comic books, newspaper comic strips, and webcomics constitute different media, but belong to one genre.

Firstly, we will consider the theoretical framework of the comics theory, focusing on the interdisciplinary character of comics scholarship. Then we will proceed to examine the shifting of the boundaries of comics genre and transmediality of comics. Finally, we will analyse a print comic and a webcomic, which are modern adaptations of the classic fairy tale Little Red Riding Hood, using narratological and multimodal approaches.

\section{Theoretical grounds of comics studies}

A comic is a multimodal narrative, combining several modes, such as verbal, visual, and sometimes aural. Images play a key role in comics, that is why special attention should be given to the visual mode. Some theorists consider comics a monosensory medium, in which all the information is transmitted through the visual channel (even words are read instead of being heard) (McCloud 89; Groensteen 122). This paper is theoretically grounded in the works of McCloud, Kukkonen, Groensteen, Goodbrey. Researchers of comics have focused on such issues as mediality of contemporary comics, the emergent canon of literary comics, narrative practices in comics' transition from print to screen, perspectives of digital comics etc. Among comics-specific features Kukkonen names a speech bubble, a speed line and an onomatopoeic effect (24). Speed or motion lines are used to indicate motion within a static image. There are also techniques used in comics for the graphic expression of feelings, for instance pictograms, emanata (graphic signs like dashes, droplets, stars). A recognizable characteristic of comics is a frame, bounding a singular or multiple panels, which is often used to indicate the passage of time (McCloud).

In our analysis, we will apply narratological approaches to comics. In narratology the concept of the narrator has become increasingly contested. Some authors support "pan-narrator theories" and consider the narrator to be a compulsory agent of any literary work, others - an optional. Kukkonen points out that in comics, "the narrator sometimes comes to the fore as a fully-fledged personality, but sometimes the narrative only implies an ordering agency that is not personalized" (32). There are different typologies of narrators, but we will follow Genette in distinguishing between narrators located in the storyworld 
(intradiegetic) and narrators located outside of the storyworld (extradiegetic).

Verbal narration in comics may be introduced in narration boxes, speech balloons, and thought bubbles. Thon argues that narration boxes may represent the narration of an extradiegetic narrator, the spoken voice of an intradiegetic speaking narrator, the written narration of an intradiegetic writing narrator, or the internal voices of intradiegetic thinking narrators (19). Thought bubbles represent a standard strategy of subjective representation.

Another important narratological issue is focalisation. According to Mikkonen, comics use "an extremely complex scale of potential intermediate positions between subjective or internal focalisation at one end, and clearly non-character-bound perspective or external focalisation at the other" (165), besides, internal and external focalisation may be used at the same time. Focalisation may be analysed on the verbal and visual levels. Visual focalisation depends on the direction of the character's gaze (the so-called deictic gaze) and may be mediated, when a character and a reader look in the same direction and the process of viewing takes place through the character's eyes, and unmediated (Painter, Martin, and Unsworth 21). As a rule, focalisation facilitates the reader's engagement with the storyworld (Horstkotte and Pedri 350).

Multimodal approaches to narratives presuppose the analysis of interaction between different modes. There are various classifications of the text-image relations (Stöckl; Martinec and Salway; Kress and van Leeuwen; Royce; Kong; Cohn; Bateman). For instance, Martinec and Salway have introduced a detailed classification of the text-image relations, which is based on two broad categories: status and logicosemantic relations. Logico-semantic relations are divided into two large groups: expansion and projection. Expansion includes elaboration, extension, and enhancement. In elaboration the image and the text may be of the same level of generality (exposition) or the levels might be different (exemplification) and either the text can be more general than the image or vice versa. Extension is connected with adding new information and enhancement specifies circumstantial information to do with time, place, reason etc. As for projection, it accounts for cases when some information is re-represented in the other mode, for instance, diagrams that summarize texts or projection of wording in speech balloons and meaning (ideas) in thought bubbles in comics (Martinec and Salway 354-55). Kong's multi-layered framework of the image-text relations overlaps with some types of relations mentioned before, but adds some new categories. For instance, there are such 
additional categories as specification and identification under elaboration relations (213). Cohn (36) identifies four types of relations connecting texts and images: inherent (the text and the image are part of each other's structures), emergent (which are directly interfaced), adjoined (which are integrated, but not interfaced directly), and independent (which are fully separate).

\section{Transition to digital comics}

Nowadays the medium of comics is undergoing a transition (Groensteen 51), as various forms of digital comics appear. So, transmediality of comics is an important issue that has to be analysed. According to Jenkins, a transmedia story unfolds across multiple platforms, with each new text making a distinctive and valuable contribution to the whole (95).

The major question to be addressed is why comics are so popular nowadays? A comic is no longer a poorly-drawn and written story printed on the cheap paper and aimed at kids, it is a high-quality product for various audiences including adults. Besides, transition to a digital medium gives a number of advantages, including the possibility of using different display modes (slide show, fade-out, zoom in etc.), deeper immersion in the fictional world, greater degree of interactivity. As Groensteen puts it, "digital comics are intrinsically hybrid, crossfertilizing the comics system with elements borrowed from animated cartoons, video games, computer technology (mouse, keyboard), and web navigation" (75).

If even print comics remain understudied, the scholarship on digital comics is scarce and fragmented. One of the first theorists who realised the potential of a digital medium for comics was McCloud. In his work Reinventing comics McCloud states that digital comics can take any size and shape, e.g., a story can be told vertically or horizontally "like a great graphic skyline" (223). He introduces the idea of the "infinite canvas' comic (200), and though such comics indeed appeared, many readers find it difficult to navigate them. Unlike McCloud, Groensteen is not so enthusiastic about digital comics. He claims that they distort the reading experience as the physical handling of the book is missing, besides, the addition of motion and sound destroys the integrity of the printed page $(66,71)$. Goodbrey voices his concerns as for the role of animation in digital comics, namely at what point a comic ceases to be a comic and becomes an animation (194).

There are several terms for digital comics. A webcomic is a general term for comics on the Internet. Some webcomics are exact digital remediations of comics originally designed for the printed page, others 
have been designed specifically for electronic media. Webcomics offer the new storytelling possibilities, an alternative experience (e.g. an image can be modified as a reader moves the mouse over it or speech balloons may appear one by one). Besides, a left-to-right reading arrangement becomes no longer necessary, as the movement of the new panel automatically draws the reader's attention, regardless of the placement (Cohn). As a result, the reader's perception of time can be sped up or slowed down. On the other hand, the creator of webcomics can experiment with the spatial relationship between panels, for instance, by presenting parallel narratives that intersect at some point. Some researchers believe that the key feature of digital comics (and webcomics in particular) is that the reader is in control of the pace of comics unfolding by clicking on the panels (Goodbrey).

Hypercomics, unlike webcomics, exist only in a digital format and have no print equivalents. A hypercomic can be defined "as a comic with a multicursal structure" (Goodbrey 291). Cursality is the realisation by the reader that there are multiple paths of reading the narrative (Pearson and Smith 63), which can reveal different sequences of events, points of view, or even multiple endings.

Motion comics represent one more digital format, combining comics and animation. Motion comics are part of contemporary transmedial practices as they remediate print comics into a form of cutout animation with soundtracks and voiceovers. Motion comics can include either animated characters and objects or static characters with animated effects (Smith 5). Some of motion comic adaptations use a cinematic approach and omit panels and speech balloons. Motion comics as well as webcomics may be interactive, but they have to be differentiated (first of all, by the presence of moving images). Some comics theorists argue that the fact that the stories in motion comics unfold at a pace set out by their producers and not viewers makes the reading process much more passive (Kleefeld). Besides, as it has already been mentioned, the ability to control the pace is considered an important feature of comics. A possible solution may be a cycle animation (e.g., a flickering light or a waving flag), which does not progress the narrative, so the reader control is still maintained. It is also worth pointing out that some motion comics use such iconic symbols as motion lines and soundtrack symbols together with animation and sound effects "to justify their identification as comics" (Aggleton 8), though such usage seems redundant.

There are also areas of overlap and hybrid forms of comics that may pose problems for the researchers. New media and emerging digital devices and platforms are altering the production methods and 
practices of media creators. Digital nature of contemporary comics gives such advantages to both authors and readers, as flexibility and interactivity, especially if the reader has to choose among several pathways of plot development.

\section{Correlations between the traditional fairy tale Little Red Riding Hood and its comics versions}

The content of comics varies significantly, and for our study we will focus on comics based on a classic fairy tale. The literary fairy tale has undergone numerous transformations of classic plots, and these processes became the most widespread at the end of 20 - beginning of 21 century. Another modern trend is that contemporary fairy-tale transformations exceed the limits of literary narratives and turn into "a multimedial phenomenon" (Bacchilega 9) by being reproduced in films, comics, digital narratives, video games etc. We will analyse print and digital comics, which are contemporary adaptations of the classic fairy tale Little Red Riding Hood. Red Riding Hood, Superhero (Frampton) is a story about a visit of a ten-year-old Ruby (Red Riding Hood) and her mother to a grandmother's house in the woods, which is interrupted by the fight with Professor Grimm, who decided to kidnap the President of the United States (Red's grandmother). Ever After, a webcomic by Healey, depicts a reencounter of Little Red Riding Hood with the Big Bad Wolf, which sends her to a psychotic state and eventually she becomes an inmate in the asylum for 'the fantastically traumatized' inhabitants of Grimmoire.

Contemporary practices of intertextuality presuppose the existence of intertextual references at various text levels (Allen). Intertextual connections can be traced already at the level of comics titles. Red Riding Hood, Superhero contains a direct allusion to the title of the classic fairy tale Little Red Riding Hood, while Ever After is a part of a fairy-tale closing formula 'live happily ever after'. Names of the characters also allude to the fairy-tale genre. Professor Grimm from Red Riding Hood, Superhero is a werewolf, a mad scientist bent on world domination, who was bitten by a radioactive wolf. His name has allusions to the Brothers Grimm, the authors of one of the variants of Little Red Riding Hood. General Huntsman's name alludes to a huntsman in the classic tale, who saves the girl from the wolf. The Big Bad Wolf, used in both Red Riding Hood, Superhero and Ever After is reminiscent of a Disney character.

Not only are there intertextual connections to the classic fairy tale in the comics titles and names of the characters, the text of comics also 
contains semi-quotes, in particular to parody the famous dialogue between Little Red Riding Hood and the wolf:

"My, my. What big HANDS you have! Big ... but slow." "All the better to smash you with, my dear!" "Holy moly! What big EYES you have ..." "All the better to SEAR you with, my dear!" "Oh, Mister Big Bad WolfBot! What big TEETH you have!" "All the better to EAT you with, you impertinent gnat!" (Frampton 54-56).

If in the traditional dialogue true intentions of the wolf are revealed only in his last remark, in the above example Professor Grimm (the wolf) from the very beginning demonstrates his hostile attitude to Red Riding Hood, using such words as 'to smash', 'to sear', 'to eat', 'impertinent gnat'. In Ever After a part of this dialogue is presented in the reversed order: it is the wolf who says to Little Red Riding Hood "What big eyes you have" (30).

Doležel identifies three types of postmodernist transformations: transposition, which preserves the main story, but locates it in a different temporal or spatial setting; expansion, which extends the scope of the protoworld, e.g., by constructing a pre- or posthistory; and modification, which redesigns the structure of the protoworld and reinvents the story (206-7). Red Riding Hood, Superhero may be considered an example of transposition, as the main story - a visit to a grandmother - is preserved, but instead of the spatial and temporal indefiniteness, characteristic for a traditional fairy tale, the story here takes place in modern times (with cars and airplanes) and in a particular country - the USA. Ever After is an example of expansion, as it is a sequel to the classic story, in which the events after the encounter with the wolf are described.

Among other modifications of modern comics adaptations is the absence of traditional opening and closing formulas (e.g. Once upon a time) and a happy ending: in Ever After the main heroine despite her fierce fighting doesn't manage to escape the asylum. Besides, both heroines do not resemble a gullible and naïve Little Red Riding Hood from the classic fairy tale, on the contrary, they are active, do not rely on saviours, but try to save themselves and others.

Events in the analysed comics are presented both with the help of an extradiegetic narrator and nonnarratorially by means of images and verbal acts between characters. The narratorial voice is usually salient at the beginning and at the end of comics. In Red Riding Hood, Superhero retrospective narration belongs almost entirely to the extradiegetic narrator. Narratorial representation establishes spatial, temporal, and causal relations between the depicted situations. Ever After contains one extended narratorial representation in the middle of the comic (16), 
where retrospective information about the protagonist is provided. The common feature of the analysed comics is that a large number of sequences of panels contain no words of the narrator or characters, only images and onomatopoeic words. Such "narration through images" (Kuhn and Veits 244) is a characteristic feature of comics. For instance, the main part of Red Riding Hood, Superhero, describing the fight between Red Riding Hood and Professor Grimm, or the depiction of an attempt of Little Red Riding Hood to escape from the asylum in Ever After use exclusively nonnarratorial verbal-pictorial representation, containing a lot of onomatopoeic words (e.g., whoosh, clink, clank, clunk, chomp etc.).

The temporal structure of the narrative in the analysed comics is nonlinear with some flashbacks. Red Riding Hood, Superhero contains retrospective panels, which refer to the protagonist's past or provide additional information about Professor Grimm. These panels are depicted in a different colour scheme (sepia or black and white, when a newspaper clipping is depicted), the beginning and the end of a flashback sequence are marked by round-shaped panels. Some temporal indicators are incorporated into narratorial representation ("Meanwhile, back at the rest stop ..." (67)), but mostly "it is the image that carries temporal indicators" (Groensteen 54). Ever After begins with the description of Little Red Riding Hood's attempt to escape from the asylum, killing the guards, and later on the reader finds out what preceded it. A nonlinear narrative is one more modification of the classic fairy tale, in which the events unfold in a linear chronological way.

Spatial indicators are present in both verbal and visual modes. For instance, in Red Riding Hood, Superhero the narratorial voice informs the reader that the protagonist's grandmother is the President of the United States, and images confirm the reader's assumption that the events of the comics take place in this country (e.g., pictures of the American flag, American Eagle, a road sign "Camp David 10 miles" (42)). It becomes clear from the narratorial presentation that the action of Ever After takes place in Grimmoire - the fairytale land.

Narratorial focalisation is connected with the narrator's filtering of events. In the analysed comics the extradiegetic narrator often becomes the external focaliser. Conversely, character-bound focalisation is internal. A direct gaze is a medium-specific marker in comics signaling focalisation. Kress and van Leeuwen point out that such gaze "creates a visual form of direct address" (117). Both paper and digital comics contain multiple examples of such focalisation-marking device as eyeline match, when in the first of the sequence of two panels a character looks at somebody or something, and the next panel has the 
image of that character or object. These are instances of mediated focalisation, because the reader sees the image from the character's point of view. Another example of mediated focalisation is the over-theshoulder shot. In Red Riding Hood, Superhero the protagonist, who is turned backwards to the reader, looks out of the window, thinking "It looks like ol' Professor Grimmy is up to his old tricks again!" (44). In a similar way in one of panels in Ever After the reader can see Little Red Riding Hood observe the surroundings or in another panel see over the wolf's shoulder the girl trying to get into her granny's house $(18,20)$. An example of mediated inferred focalisation may be found in Ever After (3), when the reader sees a lot of guards with weapons pointed at him/her through Little Red Riding Hood's eyes. One more cinematographic device, used in the analysed comics, is a high-angle shot. For instance, in Red Riding Hood, Superhero the reader looks down on the protagonist, who is soaring up in the sky (47), while in Ever After (7) the reader from the same above position observes how guards are shooting at Little Red Riding Hood who is flying above them - we may call it focalisation from above (or bird's eye).

Colours play an important role in any narrative containing visual components. While panels in Red Riding Hood, Superhero are both coloured and black and white (to indicate a retrospective narrative), Ever After is made entirely in black and white. Besides, words of the wolf in Ever After are given in white letters on a dark background, which makes them salient compared to words of other characters. It is also worth mentioning that Red Riding Hood's red outfit in Red Riding Hood, Superhero is the transmedial allusion to the Superman's cape from the Disney cartoon.

The page layout is an essential comics element that "gives overall coherence to the narrative discourse" (Groensteen 96). The size and the shape of each panel are adapted to its content. Red Riding Hood, Superhero and Ever After have the irregular page layout, as the number of panels on the page, their size, and the form of frames vary. For instance, when we first see the protagonist of Ever After walking to her grandmother's house, a panel depicting her occupies almost an entire page (the other panel on the page is a narrow rectangular close-up of the heroine), but as soon as she sees the Big Bad Wolf, more panels of various shapes (triangular, trapezium etc.) appear on a page. The moments of highest intensity are marked with the maximum number of panels on one page: five in Red Riding Hood, Superhero and seven in Ever After. The increased number of panels on a page serves to enhance the dynamism of the story. The same function is attributed to motion lines, which indicate the characters' path of movement and which are quite 
widespread in the descriptions of fights. Such comics-specific devices as emanata have another function - to express the physical or the emotional state of characters. Namely, a question mark, which appears in a thought bubble of Little Red Riding Hood in Ever After, is used to indicate her confusion, and stars above Professor Grimm's head are depicted to express a physical state of a character after a blow to his head. Another characteristic feature of comics is that linguistic and visual signs are used to represent the aural mode. For instance, the size and boldness of letters correspond to the way they are pronounced: the bigger and bolder the letters, the louder and more emotional the speech. In a similar way jagged borders of a speech balloon can depict loud speech. In Red Riding Hood, Superhero the words of Professor Grimm "I've done it! I've finally defeated Red Riding Hood!" (58) are placed in a balloon with pointed edges to convey his loud voice and excitement.

Relations between verbal and visual modes play a significant role in multimodal texts. A number of the text-image relations may be revealed. According to Cohn's classification (36), the text in speech balloons or thought bubbles and the visual images of people who produce it form an emergent relationship. Martinec and Salway call such relations projection (352). If we analyze the text-image relations in terms of expansion, we can identify different types of elaboration relations, in particular specification and exemplification. In the case of specification, either the image makes the text more specific or, vice versa, the text makes the image more specific. In the webcomic Ever After when Little Red Riding Hood is mentioned for the first time the reader sees her image, which specifies what type of clothes she wears (a dress with a white apron and a large bow, and a cape), that she also carries a basket (17). In Red Riding Hood, Superhero a text fragment "And how did Ruby acquire the Red Riding Hood of Power, you ask?" (47) is specified by the image of a girl wearing this piece of clothing (here the reader can see its resemblance with the Superman's outfit). Moreover, the image explains what kind of power the protagonist has acquired (we see her flying in the sky). About two other supernatural abilities - super strength and powerful laser-ray vision the reader finds out later, and it is the case of exemplification relations, because super strength mentioned in the text is illustrated by the girl carrying the car turned upside down with people in it, and laser-ray vision - by her ability to see through the wall (49). Exemplification relations may also be found in Ever After between the text ("Child, look at your hands. It is there." "W.. What? Who.." "You have the means within you. Now you must kill them. You must kill them.") and the picture showing the protagonist 
with a saw in her hands (24). So, the 'means' to kill others (the saw) is only depicted and never named in the text.

There are exemplification relations connected with person deixis. In Red Riding Hood, Superhero, when the protagonist says: "Don't worry, guys ... I got this one!" (50) only the picture explains that Red Riding Hood refers to Professor Grimm. Similarly, the meaning of the phrase "Kill them now. Every one of them. ... or they will gobble you up." (25) in Ever After becomes clear only from the picture. According to Martinec and Salway, in such cases "text subordination is realized by deixis from text to image" (351).

Enhancement relations provide circumstantial information. Red Riding Hood, Superhero begins as follows: "Ruby Topper is on her way to her grandma's house in the woods to celebrate her granny's birthday" (42). A reader familiar with the classic fairy tale after reading this text imagines a girl walking alone in the woods. But the accompanying picture informs the reader that the girl travels by car and that she is not alone, but accompanied by a woman, who judging from the inscription on the car's plate ('Mom') is her mother. The picture also indicates the direction in which they move, as it contains the road sign "Camp David 10 miles". Cohn calls relations connecting the text and images in road signs inherent, because the text in this case is a part of the fictional world. In another example of enhancement relations the text provides additional circumstantial information. The picture containing a war aircraft, a hangar, and a sign "Top secret. No Aliens Here" has the text in a caption: "When she was just six years old, Ruby accompanied President Grandma on a tour of Area 54, a mysterious base somewhere in the American Southwest" (47). Despite multiple forms of interaction between visual and verbal modes, we cannot but agree with Groensteen's remark that in comics the text and the image "enter into an intimate, almost fusional relationship" (71).

\section{Conclusion}

The analysis of comics, which are transformed variants of the classic fairy tale about Little Red Riding Hood, has highlighted a number of peculiarities. Intertextual connections to the classic fairy tale have been revealed in the comics titles, names of characters, semi-quotes; modifications include a different temporal and spatial setting, extending the scope of the storyworld by creating sequels, the absence of traditional opening and closing formulas and a happy ending. Linearity of the temporal structure is violated by retrospective panels, containing characters' memories about their past, which are made in different 
colour schemes. Contemporary comics depict active heroines who do not wait for saviours and rely on themselves.

The analysis has demonstrated that comics belonging to different media have much in common. Events in them are rendered by the extradiegetic narrator or nonnarratorially with the help of images. Cinematic techniques, such as the eyeline match and the over-theshoulder shot are widely used in comics as devices of character-bound internal focalisation, and the high-angle shot - of external focalisation. Mediated character-bound focalisation helps the reader to become part of the storyworld.

Given the multimodal nature of comics, special cross-modal approaches have been used to analyse interaction between verbal and visual modes. Our analysis has identified such types of the text-image relations as specification, exemplification, and enhancement. Comics as a fast-growing genre demands further analysis, especially as regards innovative digital comics, making use of new production methods and experimental practices.

\section{Bibliography}

Aggleton, Jen. "Defining Digital Comics: A British Library Perspective." Journal of Graphic Novels and Comics 10:4, 2018: 393-409. Web. 9 Aug. 2020.

Allen, Graham. Intertextuality. Abingdon: Routledge, 2011. Print.

Bacchilega, Cristina. Fairy Tales Transformed? Twenty-First-Century Adaptations and the Politics of Wonder. Detroit: Wayne State U P, 2013. Print.

Bateman, John. Text and Image: A Critical Introduction to the Visual/ Verbal Divide. London: Routledge, 2014. Print.

Berkowitz, Jay, and Todd Packer. "Heroes in the Classroom: Comic Books in Art Education." Art Education 54 (6), 2001: 12-18. Web. 9 Aug. 2020.

Cohn, Neil. "Navigating Comics: An Empirical and Theoretical Approach to Strategies of Reading Comic Page Layouts." Frontiers in Psychology 4, 2013: n. pag. Web. 09 Aug. 2020.

Cohn, Neil. "Beyond Speech Balloons and Thought Bubbles: The Integration of Text and Image." Semiotica 197 (2013): 35-63. Print.

Doležel, Lubomir. Heterocosmica. Fiction and Possible Worlds. Baltimore: John Hopkins U P, 2000. Print.

Frampton, Otis. "Red Riding Hood, Superhero: A Graphic Novel." Far Out Fairy Tales. Ed. Sean Tulien. North Mankato: Capstone P, 2016. 39-71. Print.

Goodbrey, Daniel. "Digital Comics - New Tools and Tropes." Studies in Comics 4(1), 2013: 185-97. Web. 9 Aug. 2020.

Goodbrey, Daniel. "From Comic to Hypercomic." Cultural Excavation and Formal Expression in the Graphic Novel. Ed. Jonathan Evans and Thomas Giddens. Oxford: Inter-Disciplinary P, 2013. 291-302. Print. 
Groensteen, Thierry. Comics and Narration. Jackson: U P of Mississippi, 2013. Print.

Healey, Shaun. "Ever After." 2008. Web. 9 Aug. 2020.

<https://snafu-comics.com/swmcomic/page-1/>

Hescher, Achim. Reading Graphic Novels Genre and Narration. Berlin: De Gruyter, 2016. Print.

Horstkotte, Silke, and Nancy Pedri. "Focalisation in Graphic Narrative." Narrative 19.3 (2011): 330-57. Print.

Jacobs, Dale. Graphic Encounters: Comics and the Sponsorship of Multimodal Literacy. London: Bloomsbury Academic, 2013. Print.

Jenkins, Henry. Convergence Culture: Where Old and New Media Collide. New York: New York U P, 2006. Print.

Kleefeld, Sean. Webcomics. London: Bloomsbury, 2020. Print.

Kong, Kenneth. "A Taxonomy of the Discourse Relations between Words and Visual." Information Design Journal 14.3 (2006): 207-30. Print.

Kress, Gunther, and Theo van Leeuwen. Reading Images: The Grammar of Visual Design. London: Routeledge, 2006. Print.

Kuhn, Markus, and Andreas Veits. "Narrative Mediation in Comics: Narrative Instances and Narrative Levels in Paul Hornschemeier's The Three Paradoxes." Author and Narrator: Transdisciplinary Contributions to a Narratological Debate. Ed. Dorothee Birke and Tilmann Köppe. Berlin: De Gruyter, 2015. 235-62. Print.

Kukkonen, Karin. Studying Comics and Graphic Novels. Chichester: Wiley Blackwell, 2013. Print.

Kutch, Lynn M. (ed.) Novel Perspectives on German-Language Comics Studies: History, Pedagogy, Theory. Lanham: Lexington Books, 2016. Print.

Labarre, Nicolas. Understanding Genres in Comics. Cham: Palgrave MacMillan, 2020. Print

Martinec, Radan, and Andrew Salway. 2005. "A System for Image-Text Relations in New (and Old) Media." Visual communication 4 (3) (2005): 337-71. Print.

McCloud, Scott. Reinventing Comics: How Imagination and Technology are Revolutionizing an Art Form. New York: DC Comics, 2000. Print.

McCloud, Scott. Understanding Comics: The Invisible Art. New York: HarperCollins, 1994. Print

Mikkonen, Kai. The Narratology of Comic Art. New York: Routledge, 2017. Print.

Painter, Clare, Martin, James R., and Len Unsworth. Reading Visual Narratives: Image Analysis in Children's Picture Books. Sheffield: Equinox, 2012. Print.

Pearson, Roberta, and Anthony N. Smith (eds.) Storytelling in the Media Convergence Age: Exploring Screen Narratives. London: Palgrave MacMillan, 2015. Print.

Royce, Terry D. "Intersemiotic Complementarity: A Framework for Multimodal Discourse Analysis." New Directions in the Analysis of Multimodal Discourse. Ed. Terry D. Royce and Wendy L. Bowcher. Mahwah: Lawrence Erlbaum Associates, 2007. 63 - 110. Print. 
Smith, Craig. "Motion Comics: The Emergence of a Hybrid Medium." Writing Visual Culture 7, 2015: n. pag. Web. 09 Aug. 2020.

Stöckl, Hartmut. 2009. "The Language-Image-Text - Theoretical and Analytical Inroads into Semiotic Complexity." Arbeiten aus Anglistik und Amerikanistik 34 (2009): 203-26. Print.

Thon, Jan-Noël. Transmedial Narratology and Contemporary Media Culture. Lincoln: U of Nebraska P, 2016. Print.

Versaci, Rocco. "How Comic Books Can Change the Way our Students See Literature: One Teacher's Perspective." The English Journal 91:2 (2001): 61-7. Print.

\section{КОМИКСЫ КАК ТРАНСМЕДИАЛЬНЫЙ ФЕНОМЕН: ОТ ПЕЧАТНОГО К ЦИФРОВОМУ МЕДИУМУ}

Комиксы как динамичный жанр, который чрезвычайно быстро развивается, в последнее время привлекают все большее внимание ученых. Характерной чертой современных комиксов является трансмедиальность, т.е. выход за рамки печатной страницы и трансформация в цифровые нарративы. Переход в цифровой формат имеет ряд преимуществ, включая возможность использования различных режимов отображения, более глубокое погружение в вымышленный мир, большую степень интерактивности. Данная статья рассматривает комиксы, которые являются адаптациями классической сказки «Красная шапочка», выявляет интертекстуальные ссылки и модификации. Интертекстуальные ссылки прослеживаются на уровне заголовков, имен персонажей и их характеристик, квази-цитат, которые перефразируют оригинальные тексты, кроме того, для комиксов характерны отличные пространственновременные рамки, расширение границ вымышленного мира. Проанализированы особенности размещения панелей комикса на странице, такие специфические элементы комиксов, как рамки панелей, текстовые баллоны, линии скорости движения, пиктограммы, ономатопоэтические слова.

Печатные и цифровые комиксы анализируются с применением нарратологического и мультимодального подходов. Анализ включает такие нарратологические аспекты, как стратегии репрезентации с участием и без участия нарратора, пространственно-временная структура нарратива, внутренняя и внешняя фокализация, а также кинематографические приемы, передающие фокализацию (субъективный монтаж, кадр, снятый через плечо или с высокого ракурса). Комиксы - это мультимодальные нарративы, объединяющие несколько модусов, преимущественно визуальный $и$ вербальный. Звуковой модус представлен в комиксах лингвистическими и визуальными знаками, например, зазубренными краями текстового баллона, размером и шрифтом букв. Особое внимание уделено взаимодействию визуального и вербального модусов, в частности, отношениям между текстом и 
изображением. В ходе анализа были выявлены такие виды отношений, как спецификация, экземплификация и расширение.

Ключевые слова: комиксы, трансмедиальность, мультимодальность, цифровые комиксы, веб-комиксы, отношения между текстом и изображением, фокализация, «Красная шапочка», интертекстуальность. 